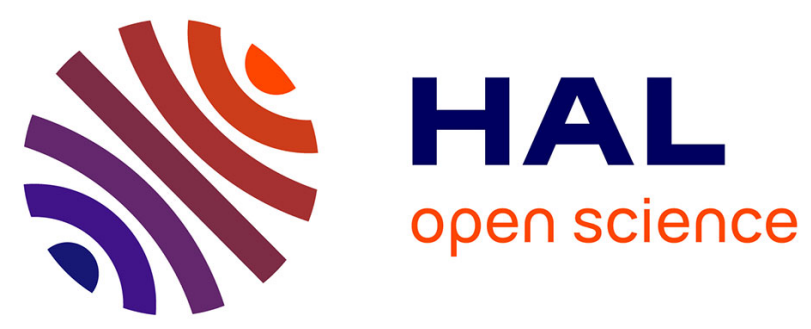

\title{
MICROSTRUCTURE AND MECHANICAL BEHAVIOUR OF Al2O3 - ZrO2 (Y2O3) ORIENTED EUTECTICS
}

L. Mazerolles, D. Michel, R. Portier

\section{- To cite this version:}

L. Mazerolles, D. Michel, R. Portier. MICROSTRUCTURE AND MECHANICAL BEHAVIOUR OF Al2O3 - ZrO2 (Y2O3) ORIENTED EUTECTICS. Journal de Physique Colloques, 1986, 47 (C1), pp.C1-335-C1-339. 10.1051/jphyscol:1986149 . jpa-00225579

\section{HAL Id: jpa-00225579 https://hal.science/jpa-00225579}

Submitted on 1 Jan 1986

HAL is a multi-disciplinary open access archive for the deposit and dissemination of scientific research documents, whether they are published or not. The documents may come from teaching and research institutions in France or abroad, or from public or private research centers.
L'archive ouverte pluridisciplinaire HAL, est destinée au dépôt et à la diffusion de documents scientifiques de niveau recherche, publiés ou non, émanant des établissements d'enseignement et de recherche français ou étrangers, des laboratoires publics ou privés. 


\title{
MICROSTRUCTURE AND MECHANICAL BEHAVIOUR OF $\mathrm{Al}_{2} \mathrm{O}_{3}-\mathrm{ZrO}_{2}\left(\mathrm{Y}_{2} \mathrm{O}_{3}\right)$ ORIENTED EUTECTICS
}

\author{
L. MAZEROLLES, D. MICHEL and R. PORTIER \\ C.N.R.S. UA 302, C.E.C.M., 15 Rue G. Urbain, F-94400 Vitry, \\ France
}

Résumé - Des eutectiques orientés $\mathrm{Al}_{2} \mathrm{O}_{3}-\mathrm{ZrO}_{2}\left(\mathrm{~V}_{2} \mathrm{O}_{3}\right)$ préparés par solidification unidirectionnelle ont été étudiés. Leur microstructure, les interfaces entre les dispersoïdes de zircone et la matrice d'alumine ainsi que les surfaces de fracture ont été observées en microscopie électronique en transmission et en balayage.

Abstract - Oriented $\mathrm{Al}_{2} \mathrm{O}_{3}-\mathrm{ZrO}_{2}\left(\mathrm{Y}_{2} \mathrm{O}_{3}\right)$ eutectics prepared by directional solidification were studied. Microstructure features, interfaces between zirconia dispersoids and the alumina matrix as well as fracture surfaces were observed by transmission and scanning electron microscopy.

\section{INTRODUCTION}

Alumina ceramics containing a fine dispersion of cubic or tetragonal zirconia particles are known to exhibit enhanced mechanical properties and especially a high fracture toughness $(1-5)$.

In order to interpret the influence of dispersoïds on the fracture behaviour, samples with controlled microstructure and crystallographic orientations were prepared at two eutectic compositions by directional solidification from the melt. Details concerning the preparative conditions and microstructural features are reported in previous papers (6-7).

The present paper deals with transmission and scanning electron microscopy observations of interfaces and fracture surfaces.

\section{MICROSTRUCTURE AND INTERFACES}

The composition and data concerning the studied eutectics are gathered in the following table.

\begin{tabular}{|c|c|c|c|c|}
\hline \multirow{2}{*}{$\begin{array}{l}\text { Composition } \\
\text { Eutectic } \\
\text { phases }\end{array}$} & \multicolumn{2}{|c|}{$\begin{array}{ccc}\mathrm{Al}_{2} \mathrm{O}_{3} & \mathrm{ZrO}_{2} & \mathrm{~V}_{2} \mathrm{O}_{3} \\
62 \mathrm{~mol}: 37 \mathrm{~mol}: 1 \mathrm{~mol}\end{array}$} & \multicolumn{2}{|c|}{$\begin{array}{ccc}\mathrm{Al}_{2} \mathrm{O}_{3} & \mathrm{ZrO}_{2} & \mathrm{Y}_{2} \mathrm{O}_{3} \\
62 \mathrm{~mol}: & 34.5 \mathrm{~mol}: & 3.5 \mathrm{~mol}:\end{array}$} \\
\hline & $\mathrm{Al}_{2} \mathrm{O}_{3}$ & $\begin{array}{l}\mathrm{ZrO}_{2}\left(3 \mathrm{~mol}_{2} \mathrm{y}_{2} \mathrm{O}_{3}\right. \\
\text { tetragonal }\end{array}$ & $\mathrm{Al}_{2} \mathrm{O}_{3}$ & $\mathrm{ZrO}_{2}\left(9 \mathrm{~mol} \div \mathrm{y}_{2} \mathrm{O}_{3}\right)$ \\
\hline $\begin{array}{l}\text { Unit cell } \\
\text { parameters }\end{array}$ & $\begin{array}{l}a=0.4756 \mathrm{~nm} \\
c=1.299 \mathrm{~nm}\end{array}$ & $\begin{array}{l}a=0.3609 \mathrm{~nm} \\
c=0.517 \mathrm{~nm}\end{array}$ & $\begin{array}{l}a=0.4756 \mathrm{~nm} \\
c=1.299 \mathrm{~nm}\end{array}$ & $a=0.5138 \mathrm{~nm}$ \\
\hline $\begin{array}{l}\text { Volume } \\
\text { fraction }\end{array}$ & 0.67 & 0.33 & 0.65 & 0.35 \\
\hline
\end{tabular}

Table 1 - Composition and constituent phases of the studied $\mathrm{Al}_{2} \mathrm{O}_{3}-\mathrm{ZrO}_{2}\left(\mathrm{Y}_{2} \mathrm{O}_{3}\right)$ eutectics. 
With the growth rates used in this study $(\cong 1-2 \mathrm{~cm} /$ hour $)$, a dendritic cellular growth occurs and zirconia particles with size about $0.5 \mu \mathrm{m}$ and interspacing about $1 \mu \mathrm{m}$ are dispersed in an alumina matrix.

The TEM image shown on Figure 1 is typical of such a microstructure.

The sample is a transverse section of an eutectic rod thinned by argon ionic bombardment. This treatment induces a preferential wear of $\mathrm{ZrO}_{2}$ particles which can be observed on the specimen edge.

Preferred directions for the simultaneous crystal growth of alumina and zirconia have been determined as well as principal epitaxy relations between $\mathrm{ZrO}_{2}$ and $\mathrm{AT}_{2} \mathrm{O}_{3}$. Preferred growth directions are $\langle 001\rangle$ and $\langle 120\rangle$ for the alumina matrix and $\langle 001\rangle$ or $\langle 110\rangle$ for zirconia dispersoids. More detailed results concerning interfaces and crystallographic relations are exposed elsewhere (L. Mazerolles, D. Michel R. Portier, to be published).

Interfaces are generaliy faceted and coherency between $\mathrm{Al}_{2} \mathrm{O}_{3}$ and $\mathrm{ZrO}_{2}$ atomic rows has been observed for planar boundaries as shown on Figure 2. This high resolution image corresponds to a $\left\{2{ }^{\top} \uparrow 0\right\}_{\mathrm{Al}_{2} \mathrm{O}_{3}} / /\{100\}_{\mathrm{ZrO}_{2}}$ observed in projection on a section $\left\{01 \overline{10} \mathrm{Al}_{2} \mathrm{O}_{3} / /\left\{010 \mathrm{ZrO}_{2}\right.\right.$. Inset represents the corresponding projection of lattice nodes and arrows indicate the regular coincidence of $\mathrm{Al}_{2} \mathrm{O}_{3}$ and $\mathrm{ZrO}_{2}$ atomic rows.

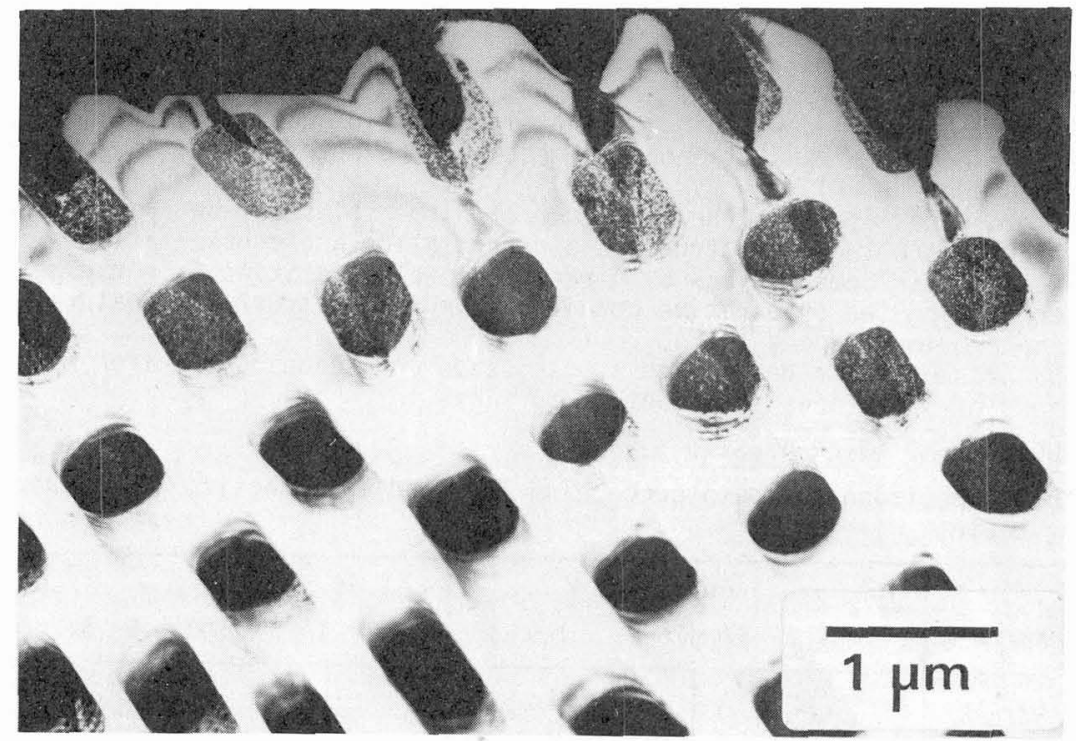

Fig. 1 - Transmission electron micrograph of a $\mathrm{Al}_{2} \mathrm{O}_{3}-\mathrm{ZrO}_{2}\left(\mathrm{Y}_{2} \mathrm{O}_{3}\right)$ eutectic. Transverse section $\{01 \overline{10}\}_{\mathrm{AT}_{2} \mathrm{O}_{3}} / /\{010\}_{\mathrm{ZrO}_{2}}$. 


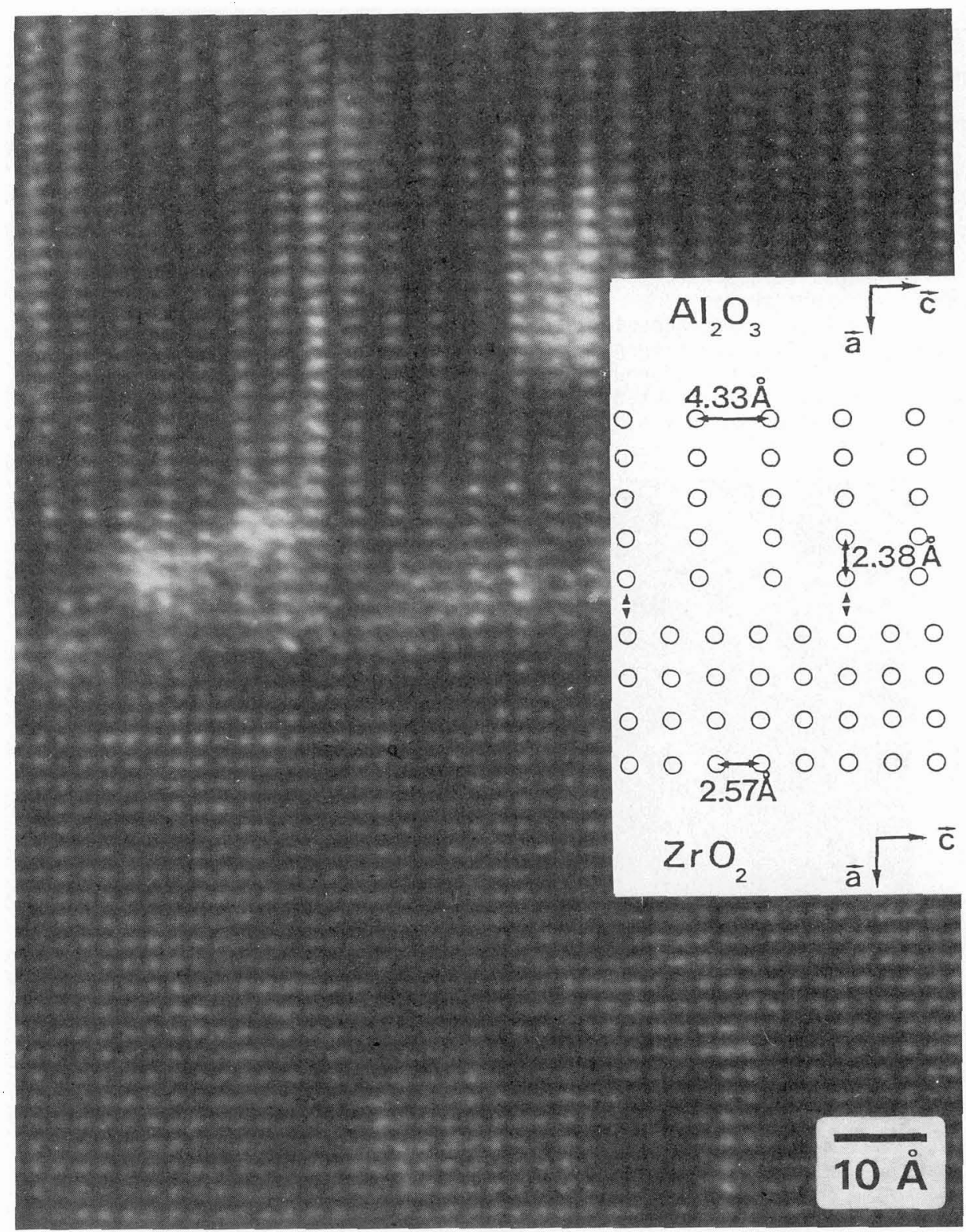

Fig. 2 - High resolution image of a $\{2 \overline{1} \overline{1} 0\}_{\mathrm{Al}_{2} \mathrm{O}_{3}} / /\left\{100 \mathrm{ZrO}_{2}\right.$ interface Transverse section $\left\{01 \overline{10} \mathrm{Al}_{2} \mathrm{O}_{3} / /\{010\}_{\mathrm{ZrO}_{2}}\right.$.

Epitaxy relations : $(0001)_{\mathrm{Al}_{2} \mathrm{O}_{3}} / /(001)_{\mathrm{ZrO}_{2}}$ $[100]_{\mathrm{Al}_{2} \mathrm{O}_{3} / /}[100]_{\mathrm{ZrO}_{2}}$. 
MECHANICAL BEHAVIOUR

Hardness and fracture toughness were measured by Vickers indentation on transverse sections of eutectic rods. Notched-beam experiments in three-point bending confirmed the $K_{I C}$ values (the length of specimen was aligned with the growth direction).

The values of hardness $H$, toughness $K_{I C}$ and Young's modulus $E$ at room temperature are the following for the $\langle 001\rangle_{\mathrm{Al}_{2} \mathrm{O}_{3} \|} \|\langle 001\rangle \mathrm{ZrO}_{2}$ orientation of a $\mathrm{Al}_{2} \mathrm{O}_{3}-\mathrm{ZrO}_{2}$ (3 mol \% $\mathrm{Y}_{2} \mathrm{O}_{3}$ ) eutectic :
$H=18 \mathrm{GPa}$
$K_{I C}=6.8 \mathrm{MPa} \cdot \mathrm{m}^{\uparrow} / 2$
$E=335 \mathrm{GPa}$

Toughness values were estimated from Vickers indentation and confirmed by notched-beam experiments.

Figure 3 shows the general aspect of the fracture surface of a $\mathrm{Al}_{2} \mathrm{O}_{3}-\mathrm{ZrO}_{2}$ $\left(\mathrm{Y}_{2} \mathrm{O}_{3}\right)$ eutectic. Fracture propagates by cleavage in the alumina matrix. At higher magnification, the roughness of the surface can be observed, especially around the location of extracted zirconia particles. These observations could explain the enhanced toughness of this material with regard to that of alumina.
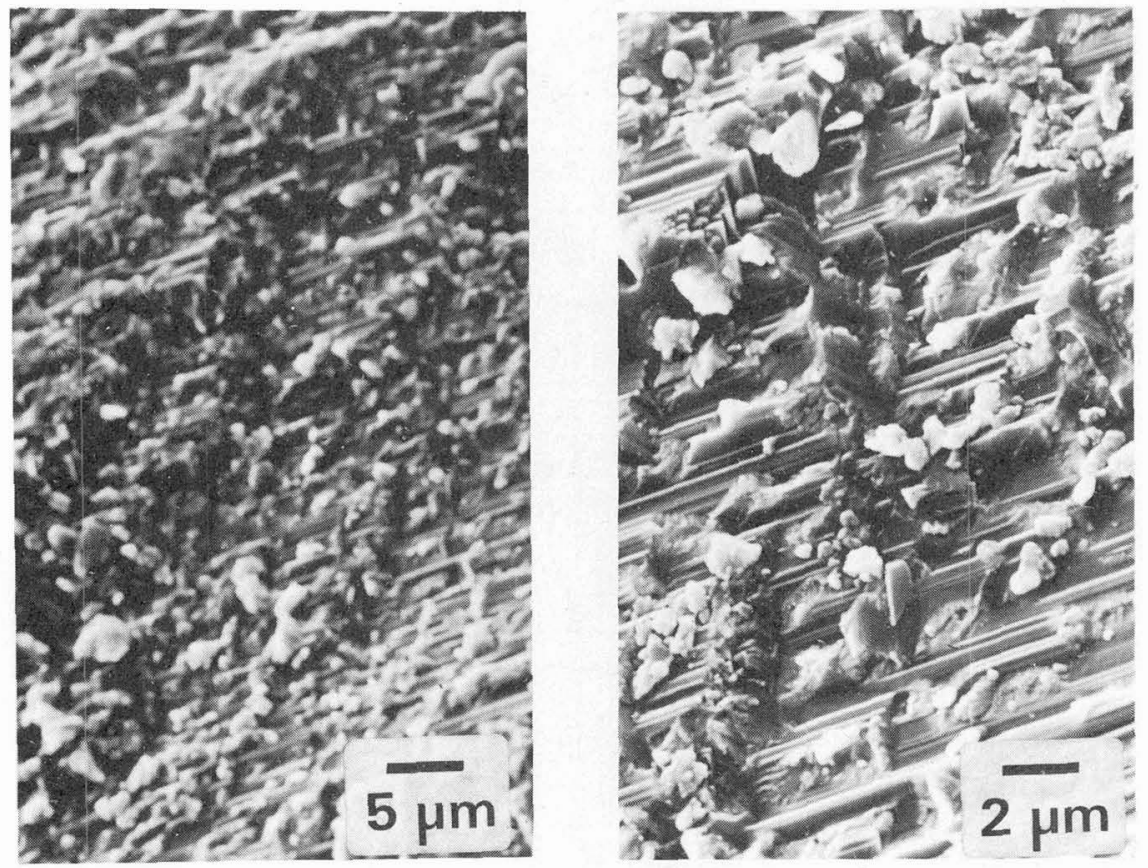

Fig. 3 - Fracture surface of a $\mathrm{Al}_{2} \mathrm{O}_{3}-\mathrm{ZrO}_{2}\left(3 \mathrm{~mol} \% \mathrm{Y}_{2} \mathrm{O}_{3}\right)$ eutectic.

\section{ACKNOWLEDGMENTS}

The authors are indebted to Drs C. Gault and B. Rogeaux (ENSCI Limoges) for measurements of mechanical properties and to J.C. Martin (CNRS Bellevue) for SEM observations. 


\section{REFERENCES}

11/ HuTse, C. and Batt, J.A., Final Rept. UARL N-910803 (1974) 10.

12/ Claussen, N., J. Am. Ceram, Soc. 59 1-2 (1976) 49.

13/ Science and Technology of Zirconia. Ed. A.H. Heuer and L.W. Hobbs Advances in Ceramics Vo1.3. The American Ceramic Society (1981).

14/ Science and Technology of Zirconia II. Ed. A.H. Heuer, N. Claussen and M. Rühte. Advances in Ceramics Vo1.12. The American Ceramic Society (1984).

/5/ Lange, F.F., J. Mater. Sci., 171 (1982) 247.

16/ Mazerolles, L., Michel, D., Perez y Jorba, M., Stud. Inorg. Chem. 3 , Ed. P. Metselaar, Heijligers and Schoonmans - Elsevier Scientific Publisher (1984) 841.

$17 /$ Michel, D., Mazerolles, L., Dallas, J.P., Stucky, M., Portier, R., Phys. Chem. Sol. State. Ed. P. Lacombe - Elsevier Science Publisher (1984) 397. 